\author{
Sergiusz Prokurat \\ Instytut Nauk Ekonomicznych Polskiej Akademii Nauk \\ sergiusz.prokurat@gmail.com
}

\title{
Ekonomiczne i prawne aspekty obrotu ziemią w Polsce na tle rynku europejskiego
}

Artykuł nadesłany: 19 czerwca 2017 r.; artykuł zaakceptowany: 4 maja 2017 r.

JEL Classification: J43, Q13, Q18, O43, P48

Keywords: land market, agricultural land, European market, agricultural properties, price of land, Poland

\begin{abstract}
Economic and legal aspects of land turnover in Poland compared to the European market

This paper discusses the regulation of agricultural land market in Poland compared to the European market in view of the increasing prices of land in Europe. It presents the causes of the increasing prices of land in Europe, including Poland, and certain historical considerations which affect the current relevancy of land in Poland and the reluctance to sell it to foreigners. The author believes that the history of agricultural land market regulation in Poland after 1989 can be divided into three periods. The first period starts with the beginnings of the economic transition and liberal, unhampered land turnover. The second dates back to 2003, when new regulations introduced certain restrictions in land turnover and land ownership. The third period is dated from the entry into force the Law of 14 April 2016, which is characterised by strict state intervention on the agricultural land market. It follows the trend of retreating from liberalization, which has recently been more intensified in Central and Eastern Europe. The article lists economic and legal factors, which restrict the functioning of agricultural land markets in Poland, and compares these regulations to selected other European countries.
\end{abstract}

\section{Wstęp}

Ziemia jest zarówno źródłem surowców, jak i miejscem produkcji rolniczej i przemysłowej. W przeciwieństwie do wszystkich innych dóbr, które mogą być kupowane i sprzedawane, ma unikatowe cechy — nie ulega procesowi dyslokacji 
(Woś 1998, s. 951) oraz jest niezniszczalna. Znajdujące się na niej budynki można zdemontować i ulokować gdzieś indziej, grunt jednak pozostanie w tym samym miejscu. Ziemia nie oznacza wyłącznie powierzchni, lecz także stanowi ściśle określoną przestrzeń gospodarczą. Jednostki wymagają miejsca, w którym mogłyby przebywać i pracować, podobnie przemysł i produkcja potrzebują obszaru dla fabryk, centrów dystrybucji lub sprzedaży detalicznej. W społeczeństwach rolniczych ziemia jest kluczowym czynnikiem wytwórczym. Całkowita ilość ziemi jako zasobu naturalnego dostępnego na naszej planecie jest skończona, a więc w przeciwieństwie do popytu, który zapewne będzie globalnie rósł wraz ze zwiększającą się liczbą ludności, jej podaż nie ulega zmianie.

Istnieje obszerna literatura na temat znaczenia dobrze funkcjonujących rynków gruntów ziemskich ${ }^{1}$, będących kluczowym czynnikiem rozwoju rolnictwa. Jeszcze więcej napisano, wskazując ich podstawową rolę we wzroście i rozwoju gospodarczym państw (Feder, Deininger 1999). Szczególne znaczenie mają instytucje dotykające kwestii własności, albowiem prawa własności wpływają bezpośrednio na każdą sferę prawną (Platteau 2000; Deininger 2003). Peruwiański ekonomista Hernando de Soto twierdzi, że kraje uznawane za bogate wyróżniają się tym, że mają prawo, dzięki któremu transakcje, oparte na poszanowaniu własności, zawierane pomiędzy ludźmi lub podmiotami gospodarczymi, prowadzą do rozwoju i bogacenia się społeczeństwa. „Tym, co tworzy kapitał na Zachodzie, jest niejawny proces, ukryty w zawiłości formalnych systemów własności” — pisze H. de Soto (2000, s. 46). Prawa własności gruntów i możliwość ich wymiany wpływają na powstawanie i efektywność działania rynków (Prokurat 2012). Dobrze funkcjonujący rynek ziemi odgrywa istotną rolę we wzroście i rozwoju gospodarczym (Feder, Deininger 1999), podobnie jak funkcjonowanie rynków nieruchomości staje się możliwe pod warunkiem istnienia odpowiednio działających rejestrów nieruchomości — katastrów, które sprawiają, że obrót jest bezpieczny.

Historycznie posiadanie ziemi jest często źródłem władzy politycznej (Binswanger, Deininger, Feder 1995; Banerjee, Iyer 2005; Baland, Robinson 2008) i przez wieki świadczyło o konkretnym statusie społeczno-ekonomicznym, stanowiąc dla posiadacza gruntów źródło tożsamości (Platteau 2000; Burton 2004). Grunty ponadto mogą służyć jako zabezpieczenie transakcji lub przejmować rolę zabezpieczenia społecznego (Falkowski 2013).

${ }^{1}$ W niniejszym artykule używam terminów: „ziemia”, „grunt”, „grunt ziemski”, „grunt rolny”, „ziemia rolna”, „ziemia rolnicza” w szerokim kontekście. Niejednokrotnie pośrednio w ramach kontekstu, wykorzystując te pojęcia, odwołuję się do precyzyjnej definicji „nieruchomości rolnej” umieszczonej w art. 46. Kodeksu cywilnego (Dz.U. z 1964 r. Nr 16, poz. 93), zgodnie z którą są to grunty, które mogą być wykorzystywane do prowadzenia działalności wytwórczej w rolnictwie, w zakresie produkcji roślinnej i zwierzęcej, nie wyłączając produkcji sadowniczej, ogrodniczej i rybnej. Nieruchomości te są położone poza terenem miast i posiadają określoną przez ustawodawcę powierzchnię minimalną. 
We współczesnych rozważaniach nad rozwojem rynków ziemi dominuje nurt integracji zagadnień politycznych, gospodarczych, społecznych i kulturowych, z włączeniem ram prawnych, polityki podatkowej i środowiskowej. Ich przedmiotem jest polityka wspierania pośredniego i bezpośredniego posiadaczy lub dzierżawców gruntów - rolników, wsparcia cen rynkowych, dotacji, subsydiów produkcyjnych, których efektem jest zmiana bodźców, wpływających na działania posiadaczy ziemi oraz zwiększenie dochodów rolników (Hertel 1989; Dewbre, Anton, Thompson 2001; Guyomard, Mouël, Gohin 2004; Ciaian, Swinnen 2006, 2009) czy zwiększenie możliwości dokonania transakcji na rynku ziemi przy założeniu istnienia niedoskonałości rynku (Eswaran, Kotwal 1986; Carter, Olinto 2003; Vranken, Swinnen 2006), a także umożliwiają ocenę produktywności gruntów oraz efektywności alokacji zasobów.

\section{Polityka Unii Europejskiej względem rolnictwa}

UE ma bogatą historię kształtowania instytucji odpowiadających za ziemię rolną. Traktat Rzymski włączył rolnictwo do wspólnego rynku Europejskiej Wspólnoty Gospodarczej $^{2}$ — w ten sposób w 1957 roku powstała Wspólna Polityka Rolna (WPR). Do jej głównych celów należało podniesienie produktywności rolnictwa, poprawa sytuacji rolników oraz umożliwienie dostępu do bezpiecznej żywności po przystępnych cenach (Chotkowski, Gaziński 2011, s. 55-71). Kolejną istotną zmianą na rynku rolnym UE było wdrożenie opracowanego w 1969 roku planu Mansholta, który wprowadzał do rolnictwa w krajach UE narzędzia polityki strukturalnej oraz kładł nacisk na zwiększoną koncentrację rolnictwa. Jednolity akt europejski z 1986 roku sprawił z kolei, że WPR uzyskała nowe cele w postaci stworzenia jednolitego rynku rolnego, wzmocnienia spójności gospodarczej i społecznej poprzez zmniejszenie dysproporcji między regionami rolniczymi oraz ograniczenie zacofania regionów o niekorzystnych warunkach rozwoju (Jurcewicz, Kozłowska, Tomkiewicz 2007, s. 16).

W 1992 roku za pomocą reformy McSharry'ego została podjęta próba zwiększenia konkurencyjności rolnictwa Wspólnoty poprzez nacisk na koncentrację areałów gospodarowania. Istotnym celem stało się ,utrzymanie na ziemiach nadających się do uprawy dostatecznej liczby rolników", co uzasadniano potrzebą zachowania środowiska naturalnego, tradycyjnego krajobrazu rolniczego Europy oraz „europejskiego modelu rolnictwa” (Błaszczyk 2001, s. 120).

Przyjęta przez UE w marcu 1999 roku Agenda 2000 była planem przyszłej polityki Unii w świetle przewidywanego powiększenia Wspólnoty. Zawierała kolejne propozycje reform WPR. Jedną z nich był plan Fishlera, uzależniający

2 EWG w 1993 roku stała się Wspólnotą Europejską, a później Unią Europejską. 
dopłaty bezpośrednie od wskaźników produkcji osiąganych przez gospodarstwa3 ${ }^{3}$. Reforma wprowadziła również zasadę wzajemnej zgodności (cross-compliance), warunkując wypłacanie rolnikom płatności od utrzymywania gruntów wchodzących w skład gospodarstwa w kulturze rolnej zgodnej z ochroną środowiska.

W wyniku zmian instytucjonalnych płatności bezpośrednie w Unii Europejskiej zostały oddzielone od produkcji rolnej, a ich nadrzędnym celem stało się wsparcie dochodów rolniczych, a nie zachęta do zwiększania produkcji. Programowanie na następne lata, 2007-2013 oraz 2014-2020, potwierdziło obrany kierunek zmian oraz systemowe wspieranie rolnictwa.

Podsumowując, europejski model rolnictwa zakłada obecność i ingerencję państwa w rynek, a ewolucja WPR stopniowo tworzyła instytucje bezpośredniego wsparcia dochodów rolniczych w zmieniającej się Unii Europejskiej, co pokazuje tabela 1.

Tabela 1. Podstawowe dane dotyczące rolnictwa UE — statystyki na przestrzeni lat

\begin{tabular}{l|c|c|c|c}
\cline { 2 - 5 } & 1962 & 1992 & 2002 & 2012 \\
\hline Liczba państw członkowskich & 6 & 12 & 15 & 27 \\
\hline Liczba rolników (w mln) & 6,5 & 7,2 & 6,2 & 13,7 \\
\hline Użytki rolne (w mln ha) & 69,0 & 118,0 & 126,0 & 172,0 \\
\hline
\end{tabular}

Źródło: opracowanie własne na podstawie bazy danych Eurostat.

\section{Wzrostowe tendencje cen ziemi w Europie}

Poziom i dynamika zmian cen gruntów rolnych na rynku europejskim charakteryzują się stosunkowo dużym zróżnicowaniem. Wśród czynników wpływających na kształtowanie się poziomu cen gruntów w poszczególnych krajach należy wymienić ich dostępność na rynku, która jest uwarunkowana między innymi zasobami, czyli udziałem tych gruntów w ogólnej powierzchni kraju, lecz także regulacjami prawnymi danego kraju w zakresie nabywania gruntów rolnych (Laskowska 2014, s. 140-149). Dynamikę zmian średnich cen za 1 ha gruntów rolnych w wybranych krajach europejskich przedstawiono na wykresie 1.

3 Od 2005 roku kraje Unii mogą oddzielać dopłaty bezpośrednie dla rolników od produkcji. W ramach reformy unijni rolnicy otrzymują dopłaty „od gospodarstwa” na podstawie średniej dopłat za lata poprzednie. O tym, co będą produkować, decydują sami, biorąc pod uwagę opłacalność produkcji. 


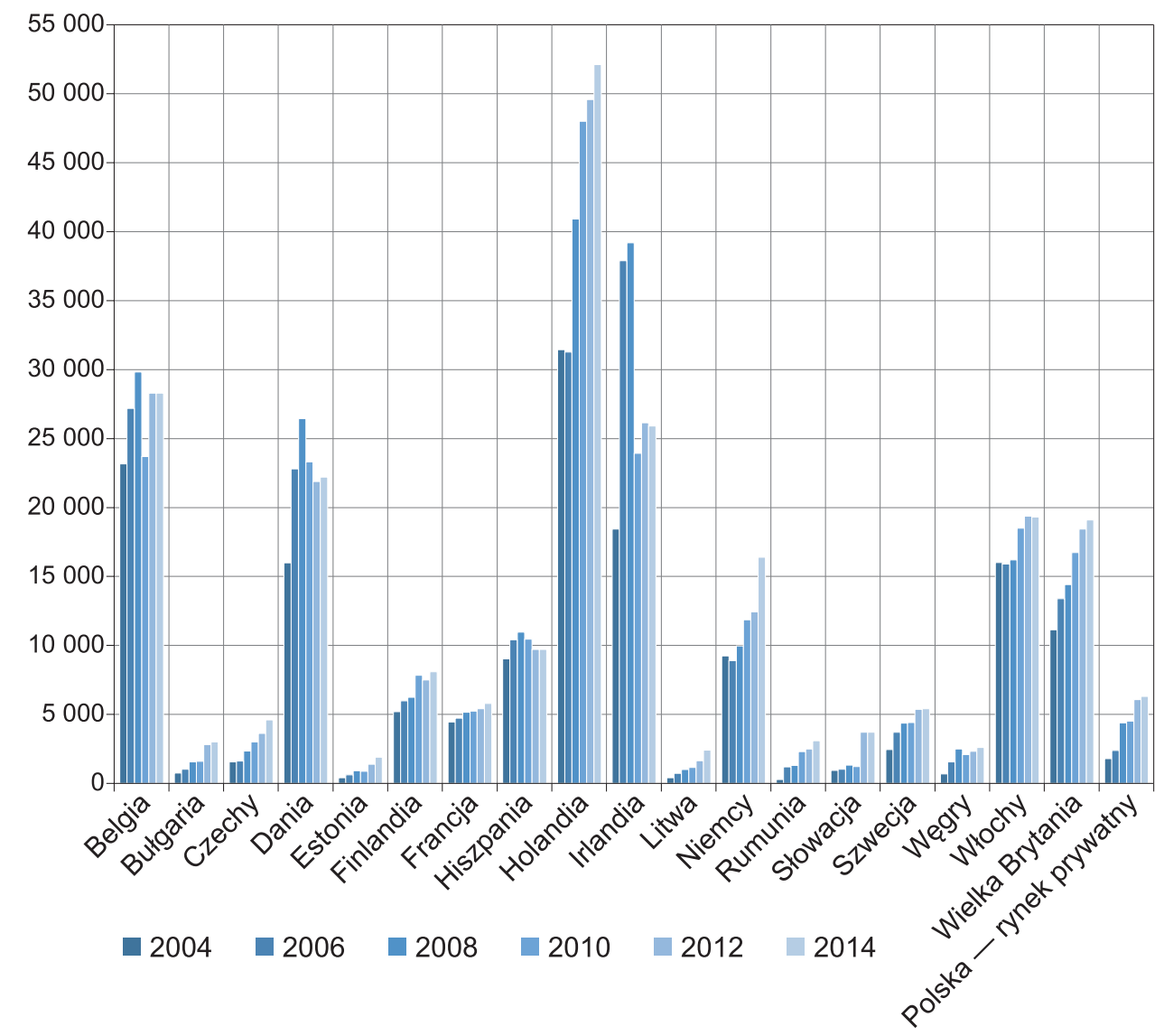

Wykres 1. Dynamika zmian cen ziemi w Europie na przestrzeni lat (w euro/ha)

Źródło: opracowanie własne na podstawie bazy danych Eurostat; Rynek ziemi rolniczej ... 2013; baza danych GUS 2015.

W latach 2004-2014 lokata kapitału w grunty rolne należała do najbardziej dochodowych. Było to szczególnie widoczne w państwach, które przystąpiły do UE w 2004 oraz 2007 roku. Przyczyn takiego stanu rzeczy jest kilka. Po pierwsze, grunty rolne w Europie przestały być traktowane jako środek produkcji przeznaczony wyłącznie dla osób związanych z rolnictwem. Rynek do stabilizacji wymaga instytucji (Rodrik 2011, s. 208), a w UE na rynku rolnym ramy instytucjonalne stworzone przez Unię sprawiły, że inwestorzy indywidualni oraz zorganizowany kapitał — zarówno krajowy, jak i zagraniczny, w tym fundusze inwestycyjne, majątkowe czy emerytalne - zaczął zwracać uwagę na wartość inwestycji w ziemię rolną. Popyt na ziemię zaczął rosnąć. Była ona jednak zbywana niechętnie - wystarczy bowiem, że plony jedynie pokryją koszty uprawy, ponieważ uprawa tak czy inaczej zapewni korzystne dopłaty przeliczane na hektar ziemi. Po drugie, rosnąca produktywność, osiągnięta dzięki wprowadzeniu i stosowaniu nowych 
technologii oraz wzrostowi kapitału ludzkiego, czyli wiedzy i umiejętności, powoduje, iż większy zysk właściciela z ziemi odzwierciedlany jest w rosnącej wartości gruntów (Romer 1990). Po trzecie, choć zawirowania na rynkach finansowych miały negatywny wpływ na europejską gospodarkę w latach 2008-2012, w części państw członkowskich odnotowano wzrost cen gruntów, gdyż ziemia rolna stała się alternatywnym sposobem na lokatę kapitału, co spowodowało dalszy wzrost jej wartości, także w wielu krajach Europy Zachodniej. Po czwarte, na poziomcen ziemi ma wpływ również zróżnicowanie regionalne, $\mathrm{w}$ tym między innymi poziom PKB per capita w danym regionie (Pietrzykowski 2014). Wzrost zamożności społeczeństwa współuczestniczy w kształtowaniu cen gruntów, podobniejak sąsiedztwo, bliskość obiektów użyteczności publicznej, dostępność komunikacyjna, stan prawny oraz stan techniczny (w tym zawartość) ${ }^{4}$. Po piąte, daje się zauważyć różnica w dynamice wzrostu cen, ponieważ ziemia w Europie Zachodniej zyskuje na wartości wolniej niż w Europie Środkowo-Wschodniej. Mogą to tłumaczyć konkretne krajowe regulacje (wymienione dalej w artykule) oraz koszty transakcyjne, zniechęcające do szybkich transakcji rynkowych. Wyższe koszty w Europie Zachodniej, między innymi podatki wymagane przy transakcjach i rejestracji ziemi (tabela 2), przyczyniają się do zachowania status quo, natomiast niższe opłaty w nowych państwach członkowskich mogą stymulować transakcje na rynku ziemi, do czego niektórzy odnoszą się (niesłusznie) jak do działań spekulacyjnych (Ciaian et al. 2012a i 2012b).

Tabela 2. Uśrednione podatki od transakcji niezbędne do rejestracji ziemi w UE (w \% wartości ziemi)

\begin{tabular}{|l|c|l|c|}
\hline \multicolumn{2}{|c|}{ Kraje Europy Zachodniej } & \multicolumn{2}{c|}{ Kraje przyjęte do UE po 2004 roku } \\
\hline \multicolumn{1}{|c|}{ Kraj } & \% wartości ziemi & \multicolumn{1}{c|}{ Kraj } & \% wartości ziemi \\
\hline Belgia & $10,00-12,50$ & Bułgaria & 0,00 \\
\hline Finlandia & 4,00 & Czechy & 3,00 \\
\hline Francja & 5,09 & Estonia & brak \\
\hline Grecja & $7,00-9,00$ & Litwa & $0,50-1,00$ \\
\hline Hiszpania & $6,00-7,00$ & Łotwa & $0,50-3,00$ \\
\hline Holandia & 0,00 & Polska & $2,00-5,00$ \\
\hline Irlandia & 9,00 & Rumunia & brak \\
\hline Niemcy & 3,50 & Słowacja & 0,00 \\
\hline Wielka Brytania & $0,00-4,00$ & Węgry & $0,50-1,00$ \\
\hline Włochy & $11,00-18,00$ & & \\
\hline
\end{tabular}

Źródło: Ciaian et al. 2012a.

4 Stan prawny i techniczny nie zależą od otoczenia. Modyfikacja stanu technicznego jest stosunkowo łatwa, natomiast stan prawny ewoluuje wraz z instytucjami. 


\section{Wzrostowe tendencje cen ziemi w Polsce}

Ziemia rolna w Polsce drożeje od początku przemian ustrojowych. Lekki spadek wystąpił tylko w latach 1999-2002. W latach 1991-2004 średnia cena ziemi rolniczej liczona $\mathrm{w}$ zł/ha wzrosła nominalnie 8-krotnie (60\% średniorocznie), a skumulowana inflacja w tym okresie wyniosła 504\% (prawie 40\% średniorocznie) (Mickiewicz, Wawrzyniak 2012, s. 255-259). Od czasu przystąpienia Polski do UE (w latach 2004-2014) następowała również szybsza aprecjacja cen gruntów rolnych (wykres 2). Wartość gruntów rolnych w Polsce od wejścia do UE wzrosła ponad 7-krotnie. Porównując średnie roczne wzrosty cen gruntów rolnych w obrocie prywatnym do inflacji, można zauważyć, że zdecydowanie przekraczają one poziom inflacji, co pokazuje wykres 3 .

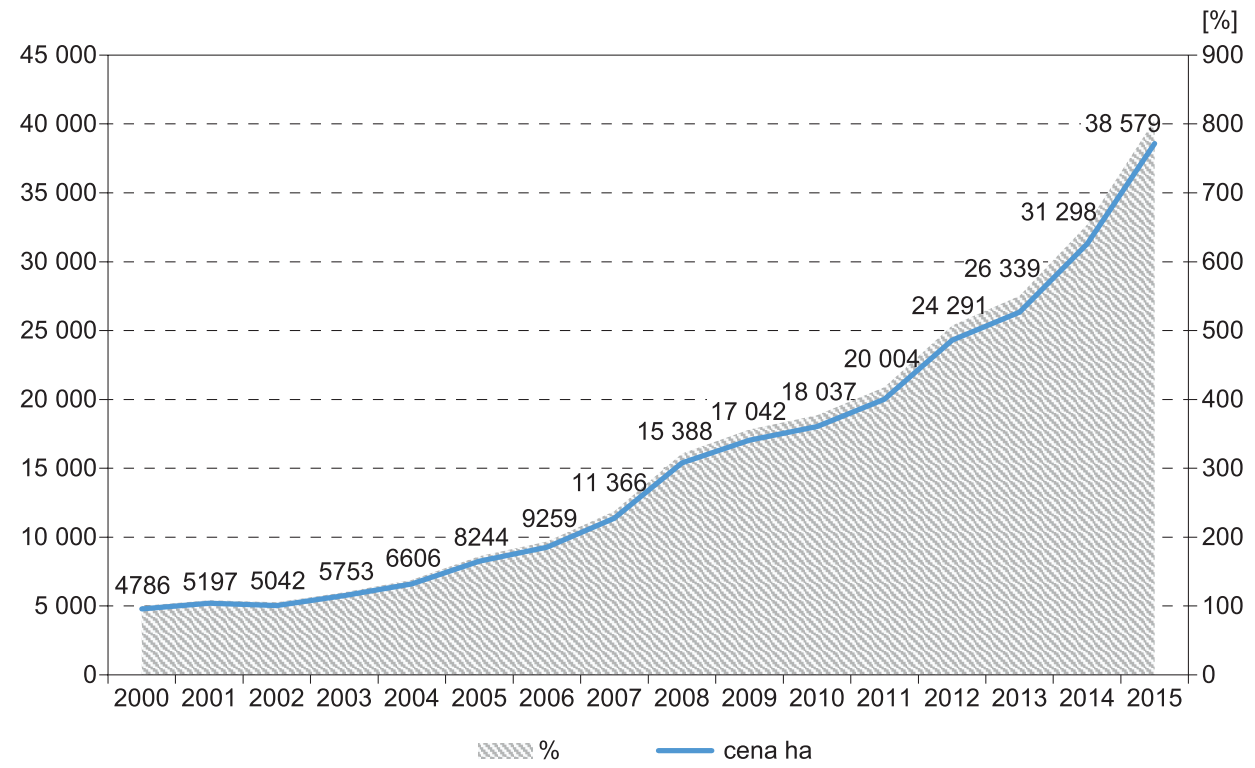

Wykres 2. Wzrost wartości ziemi w Polsce w latach 2000-2015

Źródło: opracowanie własne na podstawie bazy danych GUS 2015. 


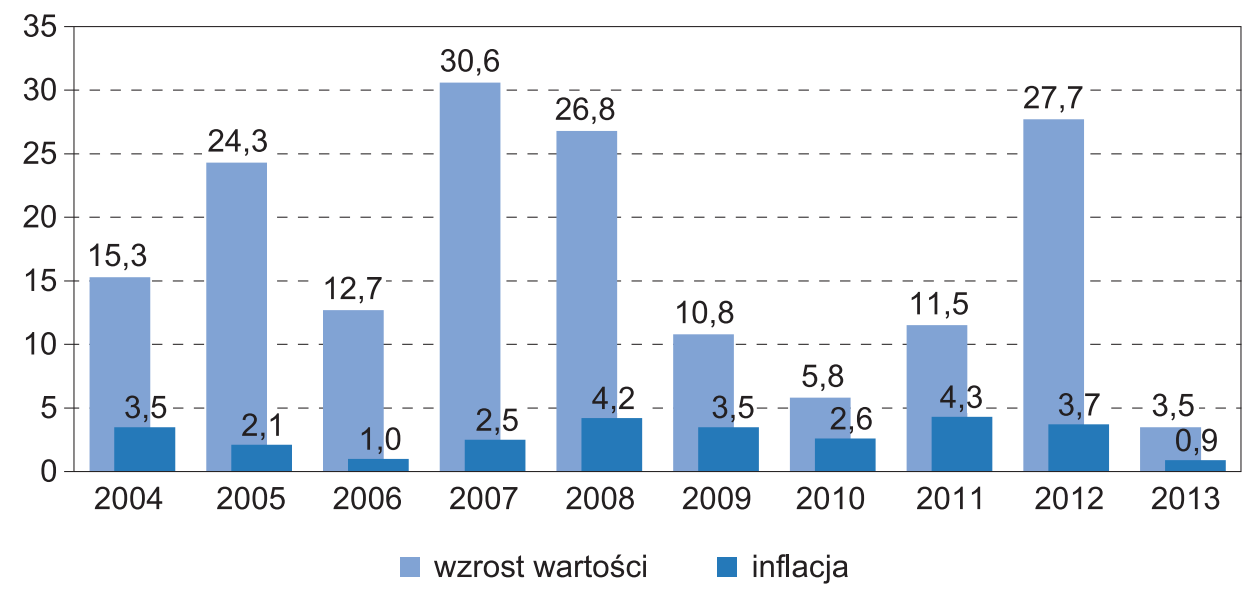

Wykres 3. Wzrost wartości ziemi w Polsce w latach 2004-2013 a inflacja (w \%)

Źródło: opracowanie własne na podstawie baz danych GUS 2015 i NBP 2015.

Mechanizmy, które wpłynęły na zmianę cen gruntów, zostały omówione przy zmianach cen ziemi rolnej w Europie. Główną przyczyną przyspieszonego wzrostu cen ziemi w Polsce było członkostwo w Unii Europejskiej od roku 2004. Spodziewane wsparcie dla sektora rolnego w formie dotacji i polityki bodźców instytucjonalnych z UE stworzyło nierównowagę pomiędzy popytem i podażą na rynku gruntów rolnych; wystąpił efekt spodziewanego wzrostu cen ziemi rolnej (Sikorska, Karwat-Woźniak, Chmieliński 2009). Ponadto posiadanie ziemi wiąże się z możliwością uczestnictwa $\mathrm{w}$ wielu programach finansowanych przez UE, które formułują bodźce stawiające przed rolnikami konkretne, nie zawsze trudne do spełnienia, wymagania (Radwan 2013). Z tych powodów ziemia stała się w Polsce pożądanym dobrem. Nawet w trakcie kryzysu w latach 2008-2009 ceny gruntów w naszym kraju wzrosły nominalnie. Tym niemniej wskutek deprecjacji złotego nastąpił spadek wartości gruntów prywatnych w 2009 roku o 10,1\% (Zadura 2010, s. 44-52).

Trzeba również nadmienić, że ceny ziemi rolniczej są wyraźnie zróżnicowane regionalnie (rysunek 1). Ziemia drożała w latach 2004-2014 szczególnie w tych regionach, gdzie wcześniej była stosunkowo tania (warmińsko-mazurskie, lubuskie, opolskie), a znacznie mniejsze wzrosty wystąpiły w regionach, które od lat wyróżniała jej wysoka wartość (kujawsko-pomorskie, wielkopolskie). Regionalne zróżnicowanie ceny ziemi rolniczej zależy przede wszystkim od kultury rolnej i kosztów produkcji generujących odpowiedni zysk. 


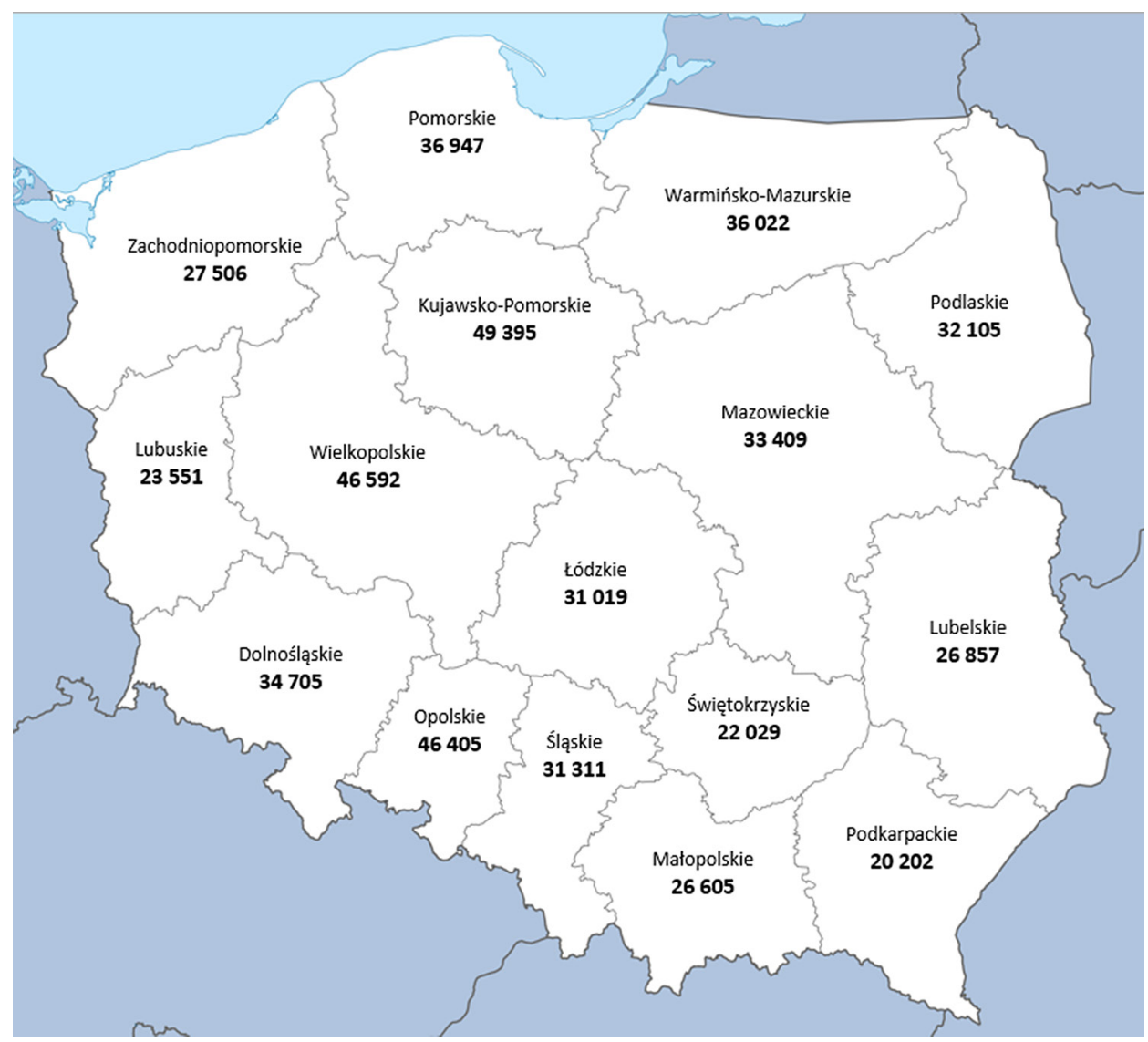

Rysunek 1. Ceny 1 ha gruntów w Polsce w II kwartale 2015 roku

Źródło: opracowanie własne na podstawie bazy danych GUS 2015.

Badania Lion's House i Interia.pl (wykres 4) wskazują, iż ziemię rolną Polacy traktują jako korzystną, nieopodatkowaną lokatę kapitału. Poza tym dla rolników są to aktywa przynoszące stały dochód (dzierżawa, środki z funduszy UE), co zniechęca do ich zbycia właścicieli i winduje cenę. 


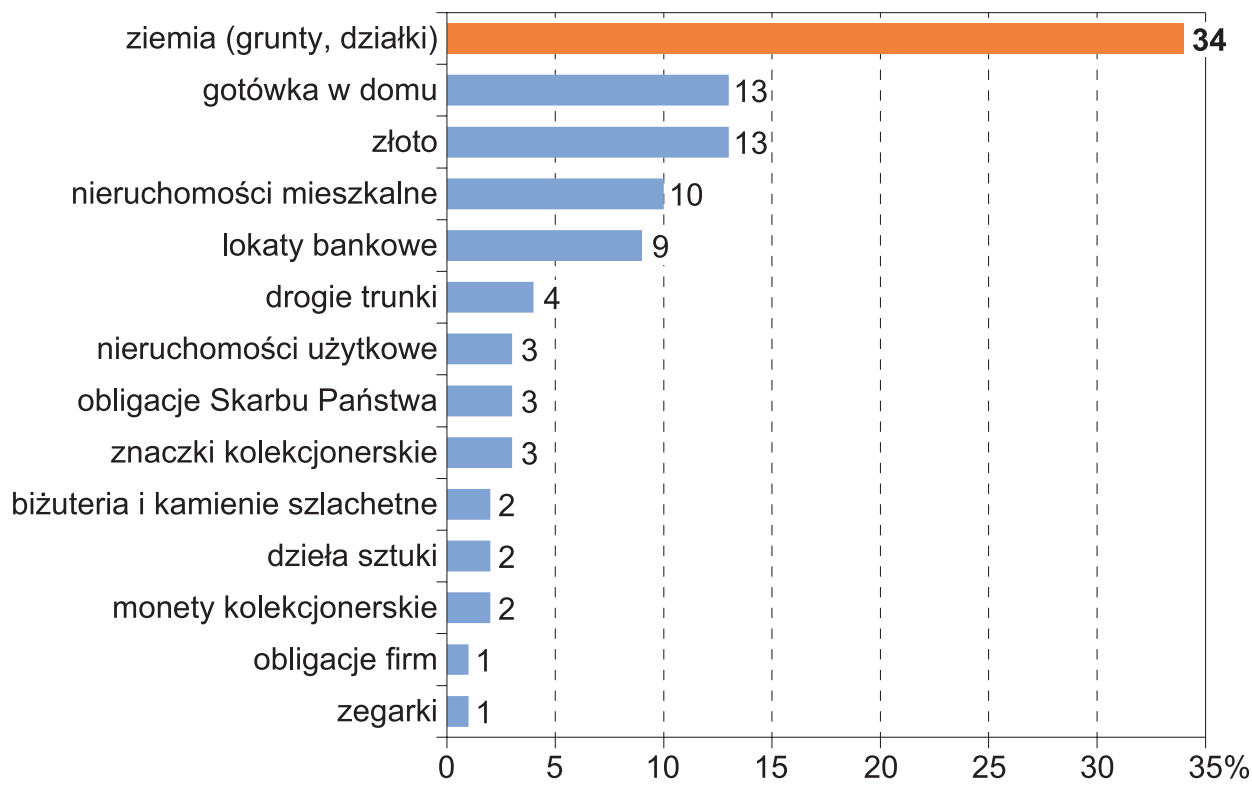

Wykres 4. Najbezpieczniejsza forma lokowania kapitału według Polaków

Źródło: opracowanie własne na podstawie badania Lion’s House i Interia.pl 2013.

\section{Znaczenie ziemi rolnej w Polsce}

Polska ma jeden z największych obszarów gruntów rolnych w Unii Europejskiej, szacowany na 9\% ogólnej powierzchni UE; w skali kraju użytki rolne stanowią 60\%. Udział rolnictwa (w tym leśnictwa i łowiectwa) w tworzeniu PKB wyniósł 2,6\%. Według Głównego Urzędu Statystycznego w I kwartale 2016 roku w rolnictwie pracowało 1702 tys. osób, co stanowi 10,6\% pracujących ogółem (GUS 2016). Średnia wielkość gospodarstwa rolnego jest w Polsce jednak dwa razy mniejsza (6 ha) niż w UE (11,9 ha) (Marks-Bielska 2009). 20\% gospodarstw ma powierzchnię zaledwie $1-2$ ha, a $32 \%-2-5$ ha; to łącznie ponad połowa spośród 1,5 mln gospodarstw rolnych (GUS 2016). Zaledwie 29\% gruntów jest dzierżawiona, co $\mathrm{w}$ porównaniu $\mathrm{z}$ innymi krajami jest stosunkowo niewielkim odsetkiem (Marks-Bielska 2013, s. 791-799).

W Polsce, podobnie jak na świecie, występuje zjawisko stałego zmniejszania się powierzchni gruntów rolnych. W latach 2002-2013 powierzchnia użytków rolnych w Polsce zmalała o 2\% (Rynek ziemi rolniczej... 2013). 


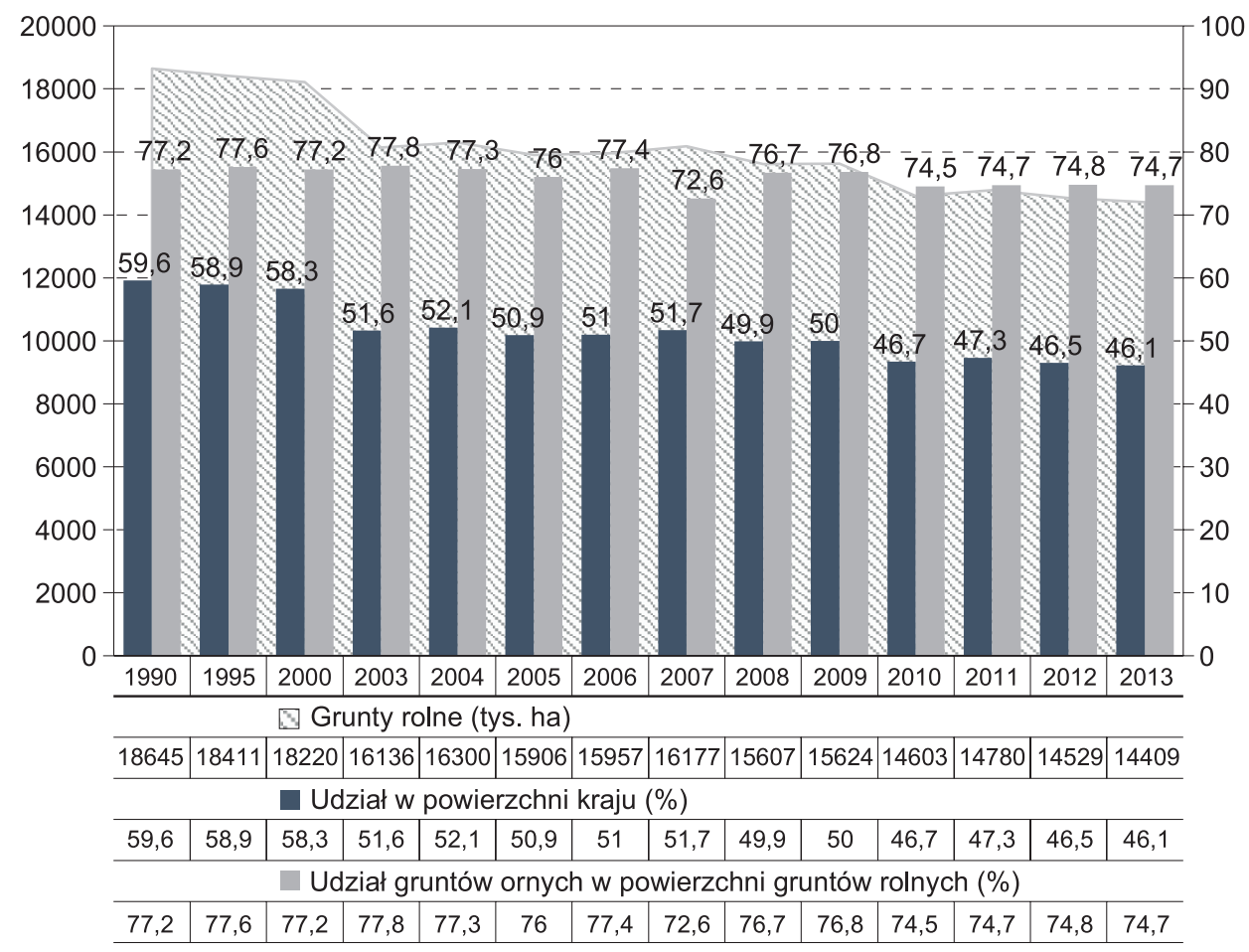

Wykres 5. Zmiany w użytkowaniu gruntów rolnych

Źródło: opracowanie własne na podstawie bazy Eurostat 2015.

Zrozumienie znaczenia ziemi rolnej w Polsce wymaga odniesienia się do pewnych faktów historycznych, ponieważ obecne instytucje związane z gruntami są głęboko zakorzenione w XIX i XX wieku (Kochanowicz 1989). Przed II wojną światową małe gospodarstwa chłopskie wspótistniały obok dużych posiadłości należących do ziemiaństwa (Mieszczankowski 1960). Grupy te różniły się w kwestii postrzegania roli ziemi. Dla drobnych posiadaczy była ona głównie samowystarczalnym źródłem produkcji żywności, przez co zapewniała im bezpieczeństwo i autonomię (Halamska 2001, s. 23-38). Ziemiaństwo postrzegało natomiast ziemię przez pryzmat władzy i pozycji społecznej (Falkowski 2013). Po przejęciu władzy przez komunistów wprowadzona została reforma, w ramach której ziemiaństwo zostało wywłaszczone, a ich majątki ziemskie rozparcelowane i podzielone na działki, które trafiły do drobnych rolników i ludności bezrolnej. W Polsce nigdy nie nastąpiła kolektywizacja rolnictwa - 75\% gruntów rolnych pozostało w małych gospodarstwach rodzinnych, a reszta została znacjonalizowana (Prosterman, Rolfes 1999). W latach 1950-1989 rynek obrotu ziemią został w dużej mierze zablokowany dla transakcji, a posiadanie własności ziemskiej, na której uprawiana była ziemia, mogło być postrzegane jako wyraz oporu polskiego społeczeństwa wobec systemu komunistycznego (Gorlach 1989, s. 23-33). Wzro- 
sło wówczas przywiązanie jednostek do ziemi, a jednocześnie nastąpiło połączenie cech chłopstwa i ziemiaństwa (Gorlach 1990).

Zagadnienia bezpośrednio związane z własnością ziemi są kluczowe dla polskich doktryn nacjonalistycznych, ponieważ $\mathrm{w}$ ich rozumieniu ziemia stanowi nie tylko ucieleśnienie bogactwa, lecz także symbol przetrwania narodu (Burger 2005). Polskie partie o charakterze nacjonalistycznym postrzegały własność ziemi jako narzędzie do osiągnięcia swojego celu, ostrzegając przed jej wykupem przez obcokrajowców. Dla nacjonalistów pojęcie ziemi funkcjonuje w kilku wymiarach. Po pierwsze, obejmuje pojęcie „matki ziemi”, która jest skarbem narodowym i należy tylko do obywateli, więc powinna być chroniona przed cudzoziemcami. Po drugie, reprezentanci takich partii chętnie wspierają instytucje antykapitalistyczne, w ramach których transakcje rynkowe są regulowane lub w skrajnym przypadku zawieszane. Po trzecie, rolnictwo w świetle doktryny nacjonalizmu preferuje małe gospodarstwa kosztem dużych, w związku z czym koncentracja ziemi jest uważana za zjawisko negatywne. Przeciwnicy integracji Polski z UE twierdzili, że liberalizacja przepisów dotyczących gruntów ziemskich spowoduje masowy wykup polskiej ziemi przez cudzoziemców (Sobol 2011). UE zgodziła się zatem na wprowadzenie okresów przejściowych, które opierały się na odstępstwach od podstawowej zasady swobody przepływu kapitału w ramach UE. Bułgaria, Czechy, Łotwa, Litwa, Węgry, Słowacja, Rumunia otrzymały okres przejściowy na 7 lat, Polska — na 12 lat.

\section{Uwarunkowania ekonomiczne i prawne obrotu ziemią w Polsce}

W historii regulacji rynku ziemi rolniczej w Polsce po 1989 roku można wyróżnić trzy okresy. Pierwszy — od początków przemian gospodarczych, gdy nastąpiła liberalizacja obrotu ziemią, polegająca na zniesieniu ograniczeń w postaci ustalonych w epoce komunizmu norm obszarowych, zasad podziału i dziedziczenia gospodarstw, regulacji związanych z zakupem gruntów państwowych oraz pozostawieniu rolnikowi pełnej swobody upraw i transakcji — ożywił prywatny rynek ziemi ${ }^{5}$. W latach 1990-1991 sprzedaż państwowych gruntów była ograniczona, a zasobami gospodarował Państwowy Fundusz Ziemi. 1 stycznia 1992 roku została powołana Agencja Własności Rolnej Skarbu Państwa (obecnie po zmianie nazwy w 2003 roku - Agencja Nieruchomości Rolnych), której zadaniem było przejęcie państwowych gruntów rolnych i gospodarowanie zasobami na zasadach określonych w ustawie z dnia 19 października 1991 roku (Dz.U. z 1991 r. $\mathrm{Nr} 107$, poz. 464). Celem stała się restrukturyzacja i prywatyzacja przejętego majątku w sposób trwały (sprzedaż, nieodpłatne przekazywanie, wniesienie aportem

5 Pojęcie gruntów rolnych reguluje Kodeks cywilny (art. 461 k.c.). 
do spółki) lub nietrwały (dzierżawa), poprzez aukcję i bezpośrednią sprzedaż, z opcją pierwokupu zarezerwowaną dla rolników (Hartvigsen 2013). Przekazany majątek stanowił wydzieloną część mienia Skarbu Państwa, która tworzy Zasób Własności Rolnej Skarbu Państwa. Ogółem przejętych zostało 4739 tys. ha gruntów, z czego zasadnicza część, ponad $80 \%$ - 3762 tys. ha, pochodziła z byłych PGR-ów. 52,87\% zostało rozdzielone pomiędzy lokalne ośrodki władzy, lasy państwowe, a także Kościoły. Około $2 \mathrm{mln}$ ha ziemi stało się przedmiotem sprzedaży (Report on the Activities... 2009). W ten sposób powstał dualny rynek, podzielony na rynek obrotu ziemią prywatną oraz rynek obrotu ziemią państwową (Marks-Bielska 2013, s. 791-799).

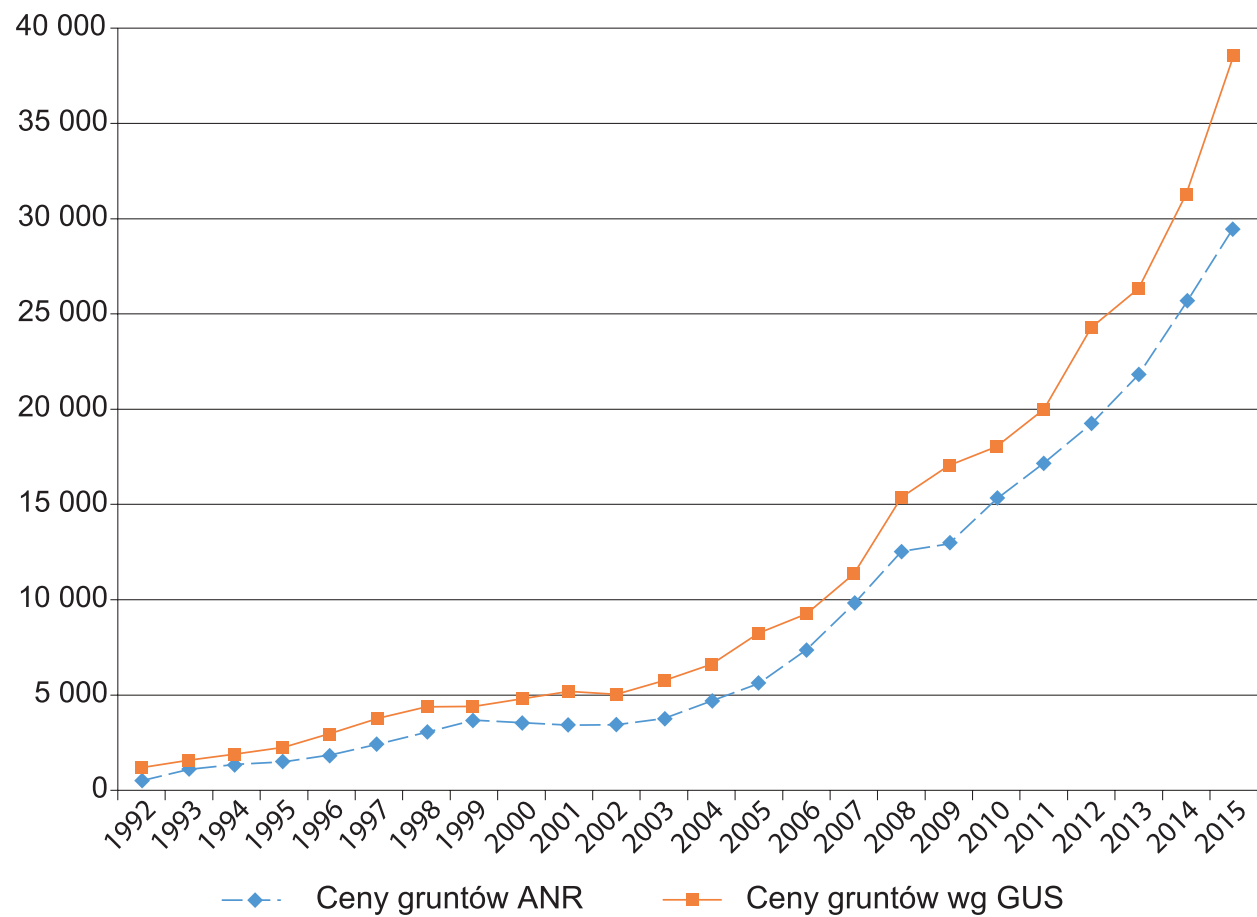

Wykres 6. Ceny sprzedaży gruntów rolnych uzyskane w obrocie prywatnym oraz państwowym (przez ANR) w latach 1992-2015

Źródło: opracowanie własne na podstawie baz danych ANR 2015 i GUS 2015.

Do drugiej połowy lat dziewięćdziesiątych rynek ziemi rolniczej w Polsce ustabilizował się i nastąpiło spowolnienie prywatyzacji. Roczna liczba transakcji obrotu na rynku państwowym wahała się pomiędzy 14-19 tys. rocznie. Istniała wówczas pełna swoboda obrotu ziemią rolniczą na rynku obrotu prywatnym. Końcem pierwszego okresu jest 16 lipca 2003 roku i wejście w życie ustawy o kształtowaniu ustroju rolnego (Dz.U. z 2003 r. Nr 64, poz. 592). 
W drugim okresie rynki obrotu ziemią rolniczą, zarówno prywatny, jak i państwowy, zostały poddane umiarkowanej interwencji państwa. Wpłynęły na to: historycznie ukształtowany symboliczny stosunek do ziemi, dziedzictwo socjalistyczne i struktura obszarowa polskiego rolnictwa, które pozostało jednym z najbardziej rozdrobnionych $\mathrm{w}$ Europie, oraz dotychczasowa preferencja posiadania ziemi zamiast dzierżawy. Inne czynniki to rosnące postrzeganie ziemi jako dobra wielofunkcyjnego oraz integracja z UE (udział w Wspólnej Polityce Rolnej) (Marks-Bielska 2010). Naczelnym celem stała się większa koncentracja gruntu w rękach rolników, motywowana faktem, że produktywność wzrasta wraz z wielkością gospodarstw (Lerman 2001). Często można spotkać się z poglądem, że polskie gospodarstwa wciąż są zbyt małe, aby konkurować na europejskim rynku rolnym (Gorton et al. 2001, s. 245-257). Ustawa z 16 lipca 2003 roku zdefiniowała również pojęcia: ,gospodarstwo rolne" - gospodarstwo rolne w rozumieniu Kodeksu cywilnego, o obszarze ponad 1 ha; ,gospodarstwo rodzinne” - obszar do 300 ha, prowadzony przez rolnika indywidualnego; „rolnik indywidualny” osoba fizyczna, będąca właścicielem lub dzierżawcą nieruchomości rolnych do 300 ha, prowadząca osobiście gospodarstwo rolne, posiadająca kwalifikacje rolnicze, zamieszkała w gminie, na obszarze której położona jest jedna z nieruchomości rolnych wchodzących w skład tego gospodarstwa. Wykonawcą zadań ustawy została ANR, która uzyskała także uprawnienia do nabywania nieruchomości rolnych od prywatnych właścicieli w celu ich późniejszej sprzedaży, głównie w celu powiększania gospodarstw rodzinnych. Nabycie miało odbywać się na podstawie prawa pierwokupu (przy umowach sprzedaży) lub przy pomocy prawa nabycia - potocznie zwanego prawem wykupu - przy innych transakcjach przeniesienia własności gruntów rolnych (np. przy umowach darowizny czy aportu).

Ustawa z 16 lipca 2003 roku nie wprowadziła zmian na rynku prywatnym, ponieważ prawo pierwokupu ANR było ograniczone. Nie obowiązywało bowiem, gdy nabywcą nieruchomości była osoba bliska sprzedającemu lub spółdzielnia produkcji rolnej (art. 3 ust. 5) albo jeśli w wyniku transakcji kupna-sprzedaży nieruchomości rolnej następuje powiększenie gospodarstwa rodzinnego (art. 3 ust. 5). Ponadto w Polsce liczba gospodarstw o powierzchni 300 ha była niewielka, więc transakcje obrotu prywatnego rynku ziemi rolniczej nie powodowały powiększania gospodarstw do powierzchni ponad 300 ha. W okresie 16 lipca 200331 grudnia 2009 roku ANR skorzystała z prawa pierwokupu jedynie 572 razy (poniżej 1\%o transakcji), kupując tylko 13,8 tys. ha użytków rolnych.

Od 2004 roku sprzedaż kształtowała się średniorocznie na poziomie około 80-100 tys. ha. Natomiast struktura transakcji gruntami rolnymi przedstawiała się następująco: transakcje rynkowe stanowiły 55\% ogółu transakcji, a obrót nierynkowy - 45\%. Spośród wszystkich transakcji rynkowych $82 \%$ zawarto pomiędzy osobami prywatnymi, a w 18\% uczestniczył sektor publiczny (Maśniak 2008). W latach 2003-2012, wskutek regulacji, przeciętna powierzchnia gruntów rolnych rolnika indywidualnego zwiększyła się z 7,4 ha do 9,3 ha (GUS 2013). 


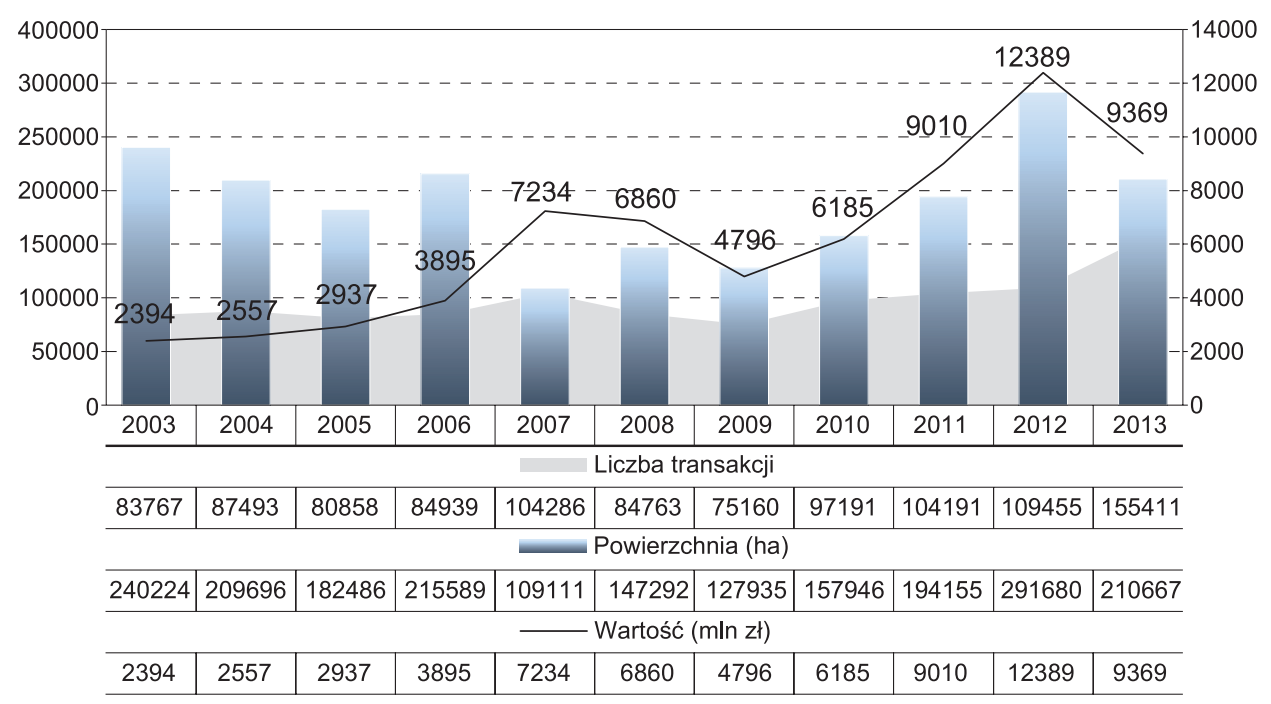

Wykres 7. Transakcje kupna-sprzedaży gruntów rolnych w latach 2003-2013

Źródło: opracowanie własne na podstawie bazy danych GUS 2015.

8 lipca 2010 roku weszła w życie ustawa z dnia 6 maja 2010 roku, nowelizująca ustawę o kształtowaniu ustroju rolnego (Dz.U. z 2010 r. Nr 110, poz. 725). $\mathrm{Na}$ jej podstawie (art. 3 ust. 4) prawo pierwokupu oraz wykupu zostały dalej ograniczone do nieruchomości rolnych mających co najmniej 5 ha powierzchni. Od tej chwili radykalnie zmniejszyła się liczba umów rozpatrywanych przez ANR oraz liczba transakcji Agencji z powołaniem się na prawo pierwokupu ${ }^{6}$.

Okres trzeci, który charakteryzuje się ścisłą interwencją państwa na rynku gruntów rolnych, datuje się na czas po 1 maja 2016 roku, czyli od wejścia w życie ustawy z dnia 14 kwietnia 2016 roku (Dz.U. z 2016 r. poz. 585). Wpisuje się ona $\mathrm{w}$ tendencje antyliberalne, narastające od pewnego czasu w Europie Środkowo-Wschodniej. Jej treść jest przedmiotem sporów.

\section{Współczesne regulacje rynku ziemi rolnej w Polsce}

Celem ustawy z dnia 14 kwietnia 2016 roku jest ograniczenie obrotu ziemią rolną w sektorze publicznym i prywatnym. Deklarowane przyczyny wprowadzenia ustawy były dwie: przeciwdziałanie spekulacji na rynku handlu ziemią oraz kończące się z dniem 1 maja 2016 roku moratorium w zakresie sprzedaży ziemi cudzoziemcom z obszaru Unii Europejskiej ${ }^{7}$. Obie przyczyny i ich geneza zostały już poruszone w niniejszym artykule.

${ }^{6}$ W okresie 1 stycznia 2010-31 grudnia 2013 roku ANR skorzystała z prawa pierwokupu tylko 37 razy, kupując zaledwie 1,1 tys. ha.

7 Ust. 4.2 akapit 1 załącznika XII do Aktu o przystąpieniu Rzeczypospolitej Polskiej do Unii Europejskiej. 
Ustawa zakłada, że w ciągu 5 lat od dnia jej wejścia w życie wstrzymuje się sprzedaż nieruchomości albo ich części wchodzących w skład Zasobu Własności Rolnej Skarbu Państwa (art. 1), z wyłączeniem między innymi nieruchomości przeznaczonych $\mathrm{w}$ planach zagospodarowania przestrzennego na cele inne niż rolne oraz nieruchomości rolnych o powierzchni poniżej 2 ha. Intencją ustawy jest również zmiana przepisów dotyczących kształtowania ustroju rolnego (art. 7) poprzez ograniczenie zakupu gruntów rolnych w sektorze prywatnym. Do tej pory wskutek ustawy z dnia 11 kwietnia 2003 roku ziemię rolną można było kupić, jeżeli ANR nie skorzysta z prawa pierwokupu. Ustawa wskazuje, że nabywcą nieruchomości rolnej może być jedynie rolnik indywidualny. Wyjątek stanowią osoby bliskie zbywcy, nabywanie w wyniku dziedziczenia, w trakcie postępowania egzekucyjnego $\mathrm{w}$ administracji, postępowania upadłościowego czy na podstawie orzeczenia sądowego. Nabywcą mogą też być jednostki samorządu terytorialnego i Skarbu Państwa ${ }^{8}$. Jednakże definicja osoby bliskiej (art. 7 pkt 3) jest do tego stopnia zawężona, że uniemożliwia właścicielowi nieruchomości rolnej dysponowanie prawem własności według własnego uznania ${ }^{9}$, o czym mówią art. 20 i 22 Konstytucji RP. Spod działania ustawy wyłączone są grunty o powierzchni 0,3 ha, które mogą być nabywane przez osoby niebędące rolnikami indywidualnymi, na przykład mieszkańców miast.

Ograniczenie swobody dysponowania nie tylko nabytą nieruchomością rolną, lecz także całym powiększonym gospodarstwem wprowadza art. 2a ust. 1 - obowiązek prowadzenia gospodarstwa rolnego, w skład którego wchodzi nieruchomość rolna, przez co najmniej 10 lat od dnia, w którym nieruchomość rolna została nabyta. W wypadku naruszenia obowiązków sąd na wniosek Agencji umożliwia nabycie nieruchomości przez Agencję za zapłatą równowartości pieniężnej odpowiadającej wartości nieruchomości (art. 9 ust. 3 pkt 1-2).

Inny kontrowersyjny element omawianej ustawy to wprowadzenie zobowiązań dla nabywcy (art. 6 pkt 9), które zakładają, że zakup gruntów rolnych z Zasobu Własności Rolnej Skarbu Państwa wymaga osobistego prowadzenia na tej nieruchomości działalności rolniczej, nieustanawiania na nabytej nieruchomości hipoteki, nieprzenoszenia własności rolnej nabytej z ZWRSP przez 15 lat oraz oświadczenia o pochodzeniu pieniędzy na nabycie nieruchomości, a także oświadczenia, iż nabywanie nie jest wykonane po to, by zbyć ziemię. Stanowi to daleką ingerencję w prawa własności, a nadzór i kontrola daje ANR (art. 7 ust. 11)

${ }^{8} \mathrm{Na}$ nabycie ziemi przez firmy lub osoby niebędące rolnikami indywidualnymi Prezes ANR będzie musiał udzielić zgodę. Zbywca będzie jednak musiał wykazać, że nie było potencjalnych nabywców wśród rolników. Wymagane jest też oświadczenie zamieszkania na 5 lat na terenie gminy, w której leży nieruchomość.

9 Art. 7 ustawy określa „osobę bliską” jako: zstępnych, wstępnych, rodzeństwo, dzieci rodzeństwa, małżonka. Pomijając między innymi synową, zięcia czy kategorię prawną „,faktycznych relacji wspólnego pożycia”. 
rygorystyczne prawo żądania dokumentów i informacji, co sprawia, że Agencja staje się narzędziem kontrolującym własność i swobodę działalności.

Kolejne kontrowersyjne elementy aktu prawnego to likwidacja prawa pierwszeństwa dla poszkodowanych w epoce komunizmu (art. 6 pkt 8), prawo pierwokupu ANR wobec spółek prawa handlowego (art. 7 pkt 6) oraz uprzywilejowanie Kościoła katolickiego i związków wyznaniowych (art. 7 pkt 4).

Ustawa z 14 kwietnia 2016 roku ogranicza handel ziemią, sprawiając, że obcokrajowcy nie są w stanie spełnić narzuconych kryteriów, więc zakup przez nich nieruchomości rolnych jest znacząco utrudniony lub nawet niemożliwy. Ustawa ingeruje jednak w prawa własności oraz prowadzi do ograniczenia transakcji, promuje dzierżawę kosztem posiadania ziemi, jednocześnie oferując ANR duże kompetencje w podejmowaniu decyzji i swobodę w interpretacji przepisów, co stwarza pole do nadużyć. Skutkiem ustawy będzie spadek liczby transakcji10, stagnacja bądź spadek cen gruntów rolnych, a wzrost cen ziemi z potencjałem do wykorzystania na cele pozarolnicze. W ten sposób powstaje bodziec dla gmin sąsiadujących z miastem, a mających w swoim obrębie nieruchomości rolne, do objęcia ich planem zagospodarowania i sprzedaży.

Choć sama ustawa nie jest sprzeczna z Traktatem o funkcjonowaniu Unii Europejskiej (art. 345 TFUE), zachodzi podejrzenie, że wiele przepisów może być sprzecznych z Konstytucją RP. Ponadto dotychczasowe orzecznictwa Trybunału Sprawiedliwości UE wskazują, że wybrane artykuły ustawy mogą zostać zakwestionowane przez Komisję Europejską. Ustawa utrudnia również budowę domów na gruntach rolnych przy hipotece na gruntach. Ponieważ brak rynku wolnego obrotu ziemią rolną skutkuje tym, że banki nie chcą przyjmować zabezpieczenia, jakim jest ziemia rolna, to instytucja finansowa może uznać, że zabezpieczenie transakcji jest niewystarczające i zażądać dodatkowego zabezpieczenia, a nawet natychmiastowej spłaty kredytu ${ }^{11}$. Banki odrzucają też wnioski kredytowe rolników, którzy jako zabezpieczenie proponują ziemię rolną. Nowelizacja ustawy zminimalizowała problem ${ }^{12}$, pozostawiając jednakże nieufność na linii bank-kredytobiorca.

\section{Regulacje dotyczące gruntów rolnych w krajach UE}

Artykuł 345 Traktatu o funkcjonowaniu Unii Europejskiej stanowi, że traktaty nie przesądzają w żadnym przypadku zasad prawa własności w państwach członkowskich. Ta reguła została wykorzystana przez wiele krajów do przygotowania

\footnotetext{
10 Zjawisko to jest potwierdzone empirycznie - Ptak 2017.

11 Przepisy stanowiły, iż suma hipoteki na nieruchomości rolnej nie może przewyższać jej wartości rynkowej.

12 Na podstawie Dz.U. z 2016 r. poz. 585. Właściciel gruntu oraz bank będą wspólnie ustalać wartość nieruchomości rolnej przy udzielaniu kredytu hipotecznego.
} 
własnych regulacji w zakresie obrotu nieruchomościami rolnymi. W niektórych państwach UE ceny gruntów, kontrakty kupna, sprzedaży i dzierżawy są zatem regulowane.

Podstawy instytucjonalne dotyczące gruntów rolnych oraz zakres regulacji są różne w Europie Zachodniej i Wschodniej w zakresie instytucji dotyczących obrotu ziemią oraz rynków dzierżawy ziemi (Swinnen, Knops 2013). Ocena restrykcyjności regulacji instytucji i rynków ziemskich jest możliwa dzięki zebraniu ze wszystkich krajów UE informacji o stopniu ochrony najemcy (TPI), ochrony użytkownika ziemi (OPI), ochrony właściciela oraz środków prawnych, które mają zapobiegać fragmentacji ziemi. Efektem jest indeks regulacji ziemskich (Total Land Regulation Index), który wskazuje stopień restrykcyjności obrotu ziemią w danym kraju (wyższa wartość = większa restrykcyjność). Jego ilustracja jest przedstawiona na wykresie 8 (stan z roku 2014, sprzed wprowadzenia w Polsce ustawy z dnia 14 kwietnia 2016 roku oraz restrykcji z Litwy, Łotwy, Słowacji, Rumunii, Węgier i Bułgarii). Wskazuje to, że polskie przepisy, nawet przed wejściem w życie ustawy z dnia 14 kwietnia 2016 roku, były jednymi z bardziej restrykcyjnych w Europie.

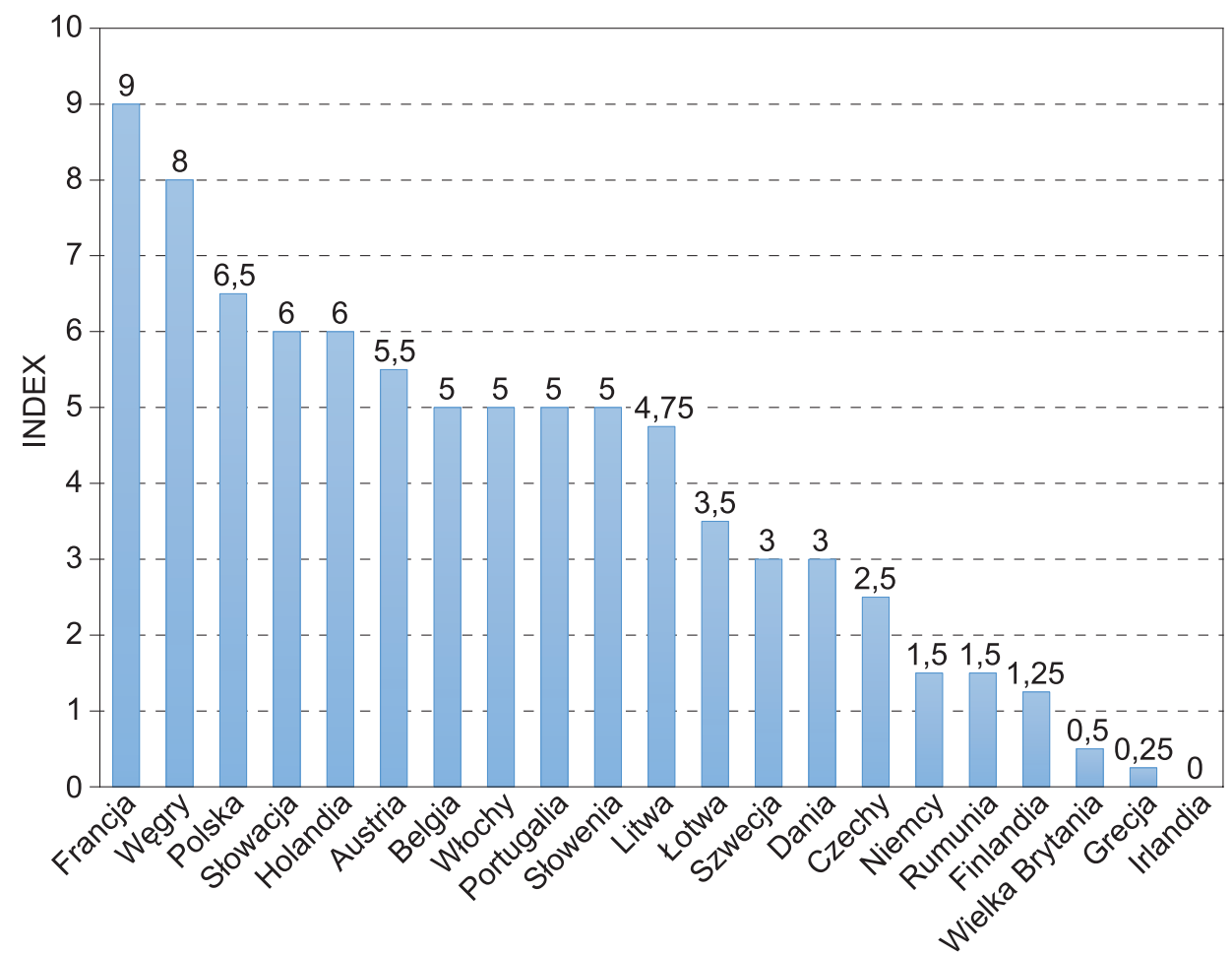

Wykres 8. Indeks regulacji ziemskich (Total Land Regulation Index)

Źródło: opracowanie własne na podstawie Swinnen, Van Herck, Vranken 2014. 
Unijne przepisy prawa dotyczące obrotu ziemią w sposób szczególny traktują pewną grupę gospodarstw - gospodarstwa rodzinne (Czyżewski, Stępień 2012). Poniżej przestawiamy przykłady regulacji rynku obrotu ziemią rolną w kilku państwach UE ${ }^{13}$.

Regulacje funkcjonujące we Francji od 1960 roku zakładają, że obrót ziemią rolną podlega SAFER (Sociétés d'Aménagement Foncier et d'Etablissement Rural), która ma prawo pierwokupu sprzedawanej ziemi rolnej oraz bierze udział w negocjacjach handlowych, tak aby trafiła ona do osób faktycznie zajmujących się rolnictwem. SAFER interweniuje, jeśli transakcja ma charakter spekulacyjny, ziemia rolna ma przejść w ręce osoby niebędącej rolnikiem lub gdyby w wyniku transakcji gospodarstwo miało utracić rodzinny charakter. Ziemia należąca do SAFER sprzedawana jest $\mathrm{w}$ przetargach, w których przeprowadzana jest ocena kandydatów. SAFER dba także o: równowagę między podażą a popytem na rynku, jakość odkupywanych ziem przed ich odsprzedażą oraz decyduje o jej pozarolniczym wykorzystaniu. Sprzedaż gruntów wymaga zgody SAFER — na jej wydanie instytucja ma dwa miesiące. Prawo pierwokupu mają sąsiedzi sprzedawanego gruntu, rolnicy wywłaszczeni, młodzi rolnicy, którzy zamierzają założyć własne gospodarstwo, a także osoby pozbawione uprzednio gospodarstw. Wymagane jest wykształcenie rolnicze, 5 lat pracy w rolnictwie w ciągu ostatnich 15 lat lub 3 lata pracy na roli po ukończeniu wyższej szkoły rolniczej. Nabywca ziemi zobowiązuje się, że co najmniej przez 15 lat będzie osobiście prowadził kupione gospodarstwo, bez prawa dzierżawy lub oddania go w użytkowanie. Obywateli pozostałych państw UE obowiązują we Francji te same regulacje co Francuzów.

Przepisy funkcjonujące w Hiszpanii od 1995 roku definiują ,gospodarstwa priorytetowe". Uzyskanie takiego statusu wymaga spełnienia kilku warunków, między innymi takich jak pełne zatrudnienie przynajmniej jednej osoby, uzyskiwanie przynajmniej 50\% dochodów prowadzącego gospodarstwo z działalności rolniczej, legitymowanie się odpowiednimi kwalifikacjami, a także zamieszkiwanie w jednostce administracyjnej, w której znajduje się dane gospodarstwo, lub sąsiedniej. Gospodarstwom priorytetowym przysługuje prawo pierwokupu, jeżeli nie prowadzi to do nadmiernej koncentracji ziemi. Hiszpańskie prawo nie pozwala jednak na podział gospodarstw w wyniku spadku i transakcji zmniejszających obszar gospodarstwa poniżej minimalnej powierzchni uprawnej zapewniającej satysfakcjonujący dochód dla rodziny.

Normy niemieckie zakładają z kolei, iż transakcje ziemią rolną podlegają kontroli administracyjnej pod nadzorem Bodenverwertungs-und-Verwaltungs GmbH (BVVG). Władze mogą odmówić zgody na transakcję, gdy: zakup prowadziłby do nadmiernej koncentracji gruntów lub zakupu dokonuje osoba, która nie jest rolnikiem i nie prowadzi osobiście gospodarstwa rolnego, zakup gruntu

13 Na podstawie: Rynek ziemi rolniczej... 2015; Ciaian et al. 2012a; Ciaian et al. 2012b; Nie tylko Polska ogranicza obrót ziemią rolna... 2016. 
wskazywałby na spekulacyjny charakter, lecz także jeśli dojdzie do nieuzasadnionego gospodarczo podziału lub zmniejszenia gospodarstwa (np. jego powierzchnia spadnie poniżej 1 ha), jeśli cena rażąco odbiega od wartości gruntu, którą w takich sytuacjach ocenia się na podstawie jej wartości dochodowej, a nie rynkowej. Nabywca ponadto jest zobowiązany do używania ziemi przez 20 lat. Prawo nie pozwala na podział gospodarstw w wyniku spadku.

Zgodnie z regulacjami funkcjonującymi na Litwie od kwietnia 2014 roku nabywca musi posiadać rolnicze kwalifikacje (np. potwierdzone dyplomem ukończenia uczelni rolniczej) lub udokumentować pracę w rolnictwie. Transakcje powyżej 10 ha wymagają zgody Narodowej Służby Ziemskiej (NZT), a firmy nabywające ziemię muszą spełniać regulacje ministerstwa rolnictwa (np. „dowieść swojej żywotności ekonomicznej”). Już przed wejściem regulacji istniał górny limit posiadanych gruntów (500 ha) i nakaz udokumentowania przez nabywcę, że dochody z pracy rolniczej stanowią 50\% jego dochodów w ostatnich dwóch latach.

Przepisy na Słowacji, wprowadzone 1 czerwca 2014 roku, pozwalają nabyć grunty osobom zamieszkałym w kraju przez 10 lat lub firmom zarejestrowanym minimum 10 lat przed transakcją. Nabywca musi 3 lata prowadzić nieprzerwanie działalność rolniczą. Osoby spełniające te wymogi mają prawo pierwokupu, następnie prawo pierwokupu wystawionego na sprzedaż gruntu mają osoby z terenu danej gminy lub terenów gmin sąsiadujących, po czym — w razie braku zainteresowania ofertą - trafia ona na stronę internetową prowadzoną przez ministerstwo rolnictwa.

Regulacje funkcjonujące na Węgrzech od 2014 roku zakładają, iż nabywcy gruntów rolnych o powierzchni powyżej 1 ha muszą posiadać kwalifikacje rolnicze lub wskazać, iż co najmniej od 3 lat prowadzą nieprzerwanie działalność rolniczą na terenie Węgier. Nabywca musi również uzyskać akceptację lokalnego komitetu ziemskiego - organu reprezentującego rolników. Wymagane jest też zobowiązanie osobistej pracy na zakupionej ziemi oraz oświadczenie, iż przeznaczenie gruntu rolnego nie ulegnie zmianie przez pierwsze 5 lat, a także nie zostanie on przekazany w użytkowanie osobom trzecim. Już przed wejściem w życie niniejszych przepisów określona została maksymalna ilość gruntów, jaką można posiadać (300 ha).

W Rumunii z dniem 11 kwietnia 2014 roku wprowadzono przepisy, zgodnie z którymi oferta sprzedaży ziemi musi najpierw trafić do lokalnej administracji, która decyduje o transakcji, jeśli grunty mają mniej niż 30 ha. Z kolei obszar ziemski powyżej 30 ha wymaga zgody ministerstwa rolnictwa.

Normy funkcjonujące w Bułgarii od 7 maja 2014 roku pozwalają nabyć grunty osobom zamieszkałym w kraju przez 5 lat lub firmom zarejestrowanym w Bułgarii minimum 5 lat przed transakcją. Wymogiem jest też oświadczenie o pochodzeniu środków na zakup nieruchomości.

Przyjęcie unijnego acquis communautaire łączy się z zrozumieniem prawa i „reguł gry” w UE. Część nowo przyjętych krajów (w 2004 i 2007 roku) narusza aktualnie zasady wspólnego rynku — swobody przepływu kapitału i przedsiębiorczości w zakresie instytucji formalnych na rynkach gruntów ziemskich, 
co spotyka się z działaniami prawnymi organów unijnych przeciw regulacjom na Węgrzech, Słowacji, Litwie, Łotwie i Bułgarii ${ }^{14}$. Przepisy wprowadzone w 2016 roku w Polsce są najbardziej restrykcyjne w całej UE ${ }^{15}$.

\section{Podsumowanie}

Przyczyny głębokich regulacji rynku ziemi w Polsce mają podstawy historyczne. Natomiast zjawisko wzrostu cen gruntów rolnych w UE, w tym w Polsce, jest ściśle związane z objęciem rolnictwa mechanizmami Wspólnej Polityki Rolnej, stworzeniem „unijnego modelu rolnictwa” oraz faktem, że ziemia ma ograniczoną podaż, co przy odpowiednich warunkach sprzyja traktowaniu jej jako dobro inwestycyjne. Poddanie gruntów szczególnym normom prawnym, przeciwdziałającym spekulacji, a jednocześnie utrudniającym transakcje, jest niezasadne, gdyż zmiany te nie prowadzą do przyspieszenia poprawy struktury obszarowej gospodarstw, a do jej petryfikacji. Ponieważ ceny ziemi rolnej rosną, a równocześnie w wielu krajach powstają coraz większe ograniczenia w jej obrocie, część społeczeństwa zostaje wyłączona z dostępu do rynkowego korzystania z ziemi. Uniemożliwia to swobodny przepływ kapitału nie tylko w UE, lecz także w Polsce, i stwarza bezpodstawne uprzywilejowanie majątkowe pewnych grup oraz przeszkadza w optymalnym wykorzystaniu ziemi jako czynnika produkcji.

Nierynkowy obrót ziemią rolniczą w niewielkim stopniu wpływa na uruchamianie procesów koncentracji (Rynek ziemi rolniczej... 2011, s. 20). Koncentrację, przy jej wadach i zaletach, najpełniej wspierają procesy rynkowe i swobodny obrót gruntami. Instytucje formalne obowiązujące na rynku gruntów ziemskich mają wpływ na prawa własności, ochronę własności i dostępu do ziemi (Swinnen 2002, s. 371-394). Instytucje rynku gruntów rolnych powinny gwarantować bezpieczeństwo praw własności do ziemi, zapewniać niskie koszty transakcyjne dla

14 Komisja Europejska rozpoczęła w 2016 roku działanie przeciw Węgrom, Słowacji, Litwie, Łotwie i Bułgarii w zakresie regulacji gruntów rolnych (na podstawie informacji KE: IP/16/2102, IP/16/1827). W październiku 2017 roku Komisja przedstawiła państwom członkowskim wskazówki dotyczące regulowania sprzedaży gruntów rolnych w oparciu o orzecznictwo Trybunału Sprawiedliwości Unii Europejskiej. Jest to odpowiedź na marcowe wezwanie Parlamentu Europejskiego 2016/2141 (INI), który zwrócił się do Komisji o ustanowienie jasnych i kompletnych kryteriów regulacji rynku gruntów w celu zapewnienia równych warunków działania w zgodzie z prawem UE. Zdaniem KE państwa członkowie mają prawo do ograniczenia sprzedaży gruntów rolnych, aby chronić społeczności wiejskie oraz promować zrównoważone rolnictwo (uprzednie zezwolenie ze strony organów krajowych na nabycie gruntów, ograniczenie wielkości nabywanych gruntów, prawo pierwokupu, interwencja cenowa państwa). Niezgodne z prawem są natomiast: nakładanie obowiązków w zakresie samodzielnego prowadzenia gospodarstwa, zakazywanie spółkom zakupu gruntów, wymaganie kwalifikacji rolniczych jako warunek wstępny zakupu gruntów (na podstawie Informacji KE: IP/17/3901).

15 Restrykcyjna jest nie tylko ustawa o gruntach rolnych, lecz także nieomawiana w tym artykule Ustawa z dnia 13 kwietnia 2016 r. o zmianie ustawy o lasach (Dz.U. z 2016 r. poz. 586). 
wszystkich uczestników gry rynkowej, dostęp do kredytu, przejrzystość, otwartość i łatwość dostępu do informacji oraz możliwości działalności i tworzenia dochodu poprzez czynnik, jakim jest ziemia, przy jednoczesnej ochronie specyfiki lokalnej społeczności, jej gospodarki i środowiska naturalnego. Niewłaściwe instytucje mogą powodować powstawanie zjawiska pogoni za rentą, a władza nad obrotem ziemią rolną i ścisła kontrola nie prowadzą do budowy gospodarki rynkowej.

\section{Bibliografia}

Badanie Lion's House i Interia.pl na próbie 15 tys. badanych, 2013.

Baland J., Robinson J.A. (2008), Land and power: Theory and evidence from Chile, „American Economic Review" 98 (5).

Banerjee A., Iyer L. (2005), History, institutions, and economic performance: The legacy of colonial land tenure systems in India, „American Economic Review” 95 (4).

Baza danych ANR 2015.

Baza danych GUS.

Baza danych Eurostat 2015, http://ec.europa.eu/eurostat/data/database.

Baza danych NBP.

Binswanger H.P., Deininger K., Feder G. (1995), Power, distortions, revolt and reform in agricultural land Rrlations, „Handbook of Development Economics” 3.

Błaszczyk M.C. (2001), Ewolucja Wspólnej Polityki Rolnej, „Biuletyn Analiz UKIE” 6.

Burger A. (2005), The issue of land ownership and rural nationalism in the East Central European /ECE/countries. A case study of Hungary, International Congress, Denmark, s. 23-27.

Burton R. (2004), Seeing through the "Good Farmer's" eyes: Towards developing an understanding of the social symbolic value of productivist' behaviour, „Sociologia Ruralis” 44 (2).

Carter M., Olinto P. (2003), Getting institutions "right" for whom? Credit constraints and the impact of property rights on the quantity and composition of investment, „American Journal of Agricultural Economics" 85 (1).

Ciaian P., Swinnen J. (2006), Land market imperfections and agricultural policy impacts in the new EU member states: A partial equilibrium analysis, „American Journal of Agricultural Economics" 88, $\mathrm{nr} 4$.

Ciaian P., Swinnen J. (2009), Credit market imperfections and the distribution of policy rents, „American Journal of Agricultural Economics" 91, nr 4.

Ciaian P. et al. (2012a), Institutional factors affecting agricultural land markets, „Factor Markets Working Paper" 16, luty.

Ciaian P. et al. (2012b), Sales markets in the EU member states and candidate countries, „Factor Markets Working Paper" 12, luty.

Czyżewski A., Stępień S. (2012), Gospodarowanie gruntami rolnymi w Polsce. Propozycje zmian, „Roczniki Ekonomiczne Kujawsko-Pomorskiej Szkoły Wyższej w Bydgoszczy” 5.

Chotkowski J., Gaziński B. (2011), Drogi i bezdroża Wspólnej Polityki Rolnej, „Studia Europejskie” 4.

Deininger K. (2003), Land Policies for Growth and Poverty Reduction, World Bank Policy Research Report, World Bank, Washington DC.

Dewbre J., Anton J., Thompson W. (2001), The transfer efficiency and trade effects of direct payments, „American Journal of Agricultural Economics” 83, nr 5.

Eswaran M., Kotwal A. (1986), Access to capital and agrarian production organization, „Economic Journal" 96. 
Falkowski J. (2013), Does it matter how much land your neighbour owns? The functioning of land markets in Poland from a social comparison perspective, „Factor Markets Working Paper” 59, sierpień.

Feder G., Deininger K. (1999), Land Institutions and Land Market, World Bank Policy Research Working Paper No. 2014, Washington DC.

Gorlach K. (1989), On repressive tolerance: state and peasant farm in Poland, „Sociologia Ruralis” 29.

Gorlach K. (1990), Socjologia polska wobec kwestii chtopskiej, Kraków.

Gorton M. et al. (2001), The international competitiveness of Polish agriculture, „Post-Communist Economies" 13 (4).

Guyomard H., Le Mouël C., Gohin A. (2004), Impacts of alternative agricultural income support schemes on multiple policy goals, „European Review of Agricultural Economics” 31, nr 2.

Halamska M. (2001), Farmers and land: Between myths and reality, „Wieś i Rolnictwo” 4 (113).

Hartvigsen M. (2004), Land reform in Central and Eastern Europe after 1989 and its outcome in the form of farm structures and land fragmentation, „Land Tenure Working Paper” 24.

Hertel T. (1989), Negotiating reductions in agricultural support: Implications of technology and factor mobility, „American Journal of Agricultural Economics” 71, nr 3.

Informacja KE (IP/16/1827), 2016.

Informacja KE (IP/16/2102), 2016.

Informacja KE (IP/17/3901), 2017.

Jurcewicz A., Kozłowska B., Tomkiewicz E. (2007), Wspólna polityka rolna, Warszawa.

Kochanowicz J. (1989), The Polish economy and the evolution of dependency, [w:] D. Chirot, The Origins of Backwardness in Eastern Europe. Economics and Politics from the Middle Age until the Early Twentieth Century, Berkeley.

Laskowska E. (2014), Rynek gruntów rolnych w Polsce na tle rynku europejskiego, „Zeszyty Naukowe Szkoły Głównej Gospodarstwa Wiejskiego w Warszawie, Problemy Rolnictwa Światowego" 14 (29), z. 3.

Lerman Z. (2001), Productivity and Efficiency of Individual Farms in Poland: A Case for Land Consolidation. Paper Presented at the Annual Meeting of the American Agricultural Economics Association, July 28-31.

Marks-Bielska R. (2009), Conditions of changes in the agricultural real property market in Poland during the years 1992-2007, „Rural Development” 4, z. 1.

Marks-Bielska R. (2010), Rynek ziemi rolniczej w Polsce: uwarunkowania i tendencje rozwoju, Olsztyn.

Marks-Bielska R. (2013), Factors shaping the agricultural land market in Poland, „Land Use Policy" 30 , issue 1 .

Maśniak J. (2008), Formy obrotu ziemia rolnicza w Polsce, „Zeszyty Naukowe SGGW — Ekonomika i Organizacja Gospodarki Żywnościowej” 72.

Mickiewicz A., Wawrzyniak B.M. (2012), Porównanie ceny ziemi rolniczej przed i po wstapieniu Polski do Unii Europejskiej, „Roczniki Naukowe Stowarzyszenia Ekonomistów Rolnictwa i Agrobiznesu" 14, z. 3.

Mieszczankowski M. (2016), Struktura agrarna Polski międzywojennej, Warszawa.

Nie tylko Polska ogranicza obrót ziemia rolną. Zobacz, jak to wygląda w innych krajach UE, „Dziennik Gazeta Prawna” 15.04.2016.

Pietrzykowski R. (2014), Cena ziemi rolniczej jako wskaźnika rozwoju regionalnego, referat z IX Kongresu Ekonomistów Polskich.

Platteau J. (2000), Institutions, Social Norms, and Economic Development, Amsterdam.

Prokurat S. (2012), Prawne i ekonomiczne aspekty systemu obrotu ziemia w Indonezji, [w:] Azjatyckie życie gospodarcze na początku XXI wieku, red. J. Marszałek-Kawa, Toruń. 
Prosterman R., Rolfes L. (1999), Review of the legal basis for agricultural land markets in Lithuania, Poland, Romania, „Structural Change in the Farming Sectors in Central and Eastern Europe".

Ptak A. (2017), Ziemia rolna oczami notariuszy. Handel staną i ceny stoja, „Dziennik Gazeta Prawna” 2.01.2017.

Radwan A. (2013), Unię najlepiej doja rolnicy, „Dziennik Gazeta Prawna” 16.08.2013.

Report on the Activities of the Agricultural Property Agency of the Stock of Agricultural Property of the Treasury (2009), ANR, Warsaw.

Rocznik statystyczny 2013, GUS, Warszawa 2014.

Rodrik D. (2011), Jedna ekonomia, wiele recept. Globalizacja, instytucje i wzrost gospodarczy, Warszawa.

Romer P. (1990), Endogenous technological change, ,Journal of Political Economy” 98, nr 5.

Rynek ziemi rolniczej, stan i perspektywy (2011), „Analizy rynkowe”, Warszawa.

Rynek ziemi rolniczej, stan i perspektywy (2013), „Analizy rynkowe”, Warszawa.

Rynek ziemi rolniczej, stan i perspektywy (2015), „Analizy rynkowe”, Warszawa.

Sikorska A., Karwat-Woźniak B., Chmieliński P. (2009), Changes in the agricultural land market and agrarian structure of individual farms in Poland, „Journal of Scientific Papers Economics \& Sociology" 2, no. 1.

Sobol D. (2011), The property market in Poland as an area of investment activity of foreigners, „Oeconomia Copernicana” 2, no. 3.

Soto H. de (2000), The Mystery of Capital, New York.

Sprawozdanie Parlamentu Europejskiego 2016/2141(INI), 2017.

Swinnen J., Vranken L. (2009), Land \& EU Accesion. Review of the Transitional Restrictions by New Member States on the Acquisition of Agricultural Real Estate, „Centre for European Policy Studies".

Swinnen J. (2002), Political reforms, rural crises, and land tenure in western Europe, „Food Policy” 27 (4).

Swinnen J., Knops L. (2013), Land, labour and capital markets in european agriculture, „Centre for European Policy Studies".

Swinnen J., Van Herck K., Vranken L. (2014), Land markets regulations in Europe, „LICOS Discussion Paper" 354, no. 14.

Ustawa z dnia 23 kwietnia 1964 r. — Kodeks cywilny, Dz.U. z 1964 r. Nr 16, poz. 93.

Ustawa z dnia 19 października 1991 r. o gospodarowaniu nieruchomościami rolnymi Skarbu Państwa, Dz.U. z 1991 r. Nr 107, poz. 464.

Ustawa z dnia 11 kwietnia 2003 r. o kształtowaniu ustroju rolnego, Dz.U. z 2003 r. Nr 64, poz. 592.

Ustawa z dnia 6 maja 2010 r. o zmianie ustawy o kształtowaniu ustroju rolnego, Dz.U. z 2010 r. Nr 110, poz. 725 .

Ustawa z dnia 14 kwietnia 2016 r. o wstrzymaniu sprzedaży nieruchomości Zasobu Własności Rolnej Skarbu Państwa oraz o zmianie niektórych ustaw, Dz.U. z 2016 r. poz. 585.

Vranken L., Swinnen J. (2006), Land rental markets in transition: Theory and evidence from Hungary, „World Development” 34 (3).

Woś A. (1998), Zasoby odnawialne w agrobiznesie, [w:] Encyklopedia agrobiznesu, red. A. Woś, Warszawa.

Zadura T. (2010), Current problems of agricultural land market in European countries, „The Market of Agricultural Land - State and Perspectives. Market Analysis" 13. 